\title{
MENINGKATKAN KEAKSARAAN USAHA MANDIRI DENGAN PEMBERDAYAAN MASYARAKAT DI DESA BAHARI
}

\author{
L.M. Azhar Sa'ban ${ }^{1}$, Marsiah Ramuli ${ }^{2}$, Hasriana ${ }^{3}$, Asril Midu ${ }^{4}$ \\ ${ }^{1}$ Dosen Program Studi Ilmu Pemerintahan, Fakultas Ilmu Sosial dan Ilmu Politik \\ ${ }^{234}$ Mahasiswa Program Studi Ilmu Pemerintahan, Fakultas Ilmu Sosial dan Ilmu Politik \\ Universitas Muhammadiyah Buton \\ Email: izharrazi@gmail.com ${ }^{1}$
}

\section{Submitted: 12 Agustus 2020 Accepted:18 April 2021 Published: 30 April 2021}

\begin{abstract}
Abstrak
Pemberdayaan Perempuan Dalam Meningkatan Kewirausahaan Usaha Mandiri merupakan sebuah bentuk layanan program untuk melestarikan keaksaraan berwirausaha. Masyarakat sasaran yang diberdayakan merupakan perempuan buta aksara usia 15-59. Tujuan utama dari program ini adalah meningkatkan keberdayaan perempuan masyarakat sasaran yang buta aksara dengan usia 15-59 tahun melalui peningkatan pengetahuan, keterampilan, sikap, dan berusaha secara mandiri. Dalam hal ini, masyarakat diberikan keterampilan guna untuk mengembangkan potensi sumber daya manusia yang ada sehingga masyarakat menjadi berdaya. Pemberdayaan perempuan melalui program Keaksaraan Usaha Mandiri dalam proses kegiatan pembelajarannya menekankan pada pendidikan keterampilan yang berpeluang menjadi suatu bidang usaha yang sesuai dengan minat dan potensi yang dimiliki oleh warga perempuan sasaran. Selain itu, terdapat materi dalam kegiatan PKM meningkatkan keaksaraan usaha mandiri dengan pemberdayaan perempuan dalam yaitu: Para perempuan dalam program Keaksaraan Usaha Mandiri diberikan materi dengan metode Ceramah, Curah Pendapat, dan Diskusi. Perempuan usia 15-59 tahun yang menjadi target sasaran kegiatan pengabdian ini sangat antusias mengikuti kegiatan penyampaian materi tersebut.
\end{abstract}

Kata kunci: Pemberdayaan, Keaksaraan, Usaha Mandiri 


\section{PENDAHULUAN}

Program Keaksaraan Usaha Mandiri (KUM) merupakan kegiatan peningkatan kemampuan keberaksaraan bagi warga belajar yang telah mengikuti dan atau mencapai kompetensi keaksaraan dasar, melalui pembelajaran keterampilan usaha (kewirausahaan) yang dapat meningkatkan produktivitas warga belajar, baik secara perorangan maupun kelompok sehinggga diharapkan dapat memiliki mata pencaharian dan penghasilan dalam rangka peningkatan taraf hidupnya (Hening Ratri, 2015).

Tujuan dari Keaksaraan Usaha Mandiri adalah meningkatkan partisipasi perempuan berusia 15-59 tahun yang berkeaksaraan rendah dalam mengikuti kegiatan keaksaraan usaha mandiri. Meningkatkan keberdayaan penduduk usia 15-59 tahun yang berkeaksaraan rendah melalui peningkatan pengetahuan, sikap, dan keterampilan serta berusaha secara mandiri. Memelihara dan melestarikan tingkat keberaksaraan penduduk melalui kegiatan ragam keaksaraan.

Keaksaraan usaha mandiri adalah model pembelajaran pemberantasan dan penguatan keaksaraanwargabelajardenganmenggabungkan muatan materi pokok membaca, menulis, berhitung yang terangkum dalam keaksaraan usaha mandiri, dengan materi penunjang yaitu keterampilan fungsional berbasis pada minat, kebutuhan dan potensi pasar/ peluang pasar (Nurwahidah, n.d.).

Keaksaraan usaha mandiri meningkatkan kemampuan membaca, menulis, berhitung, mendengarkan dan berbicara untuk mengkomunikasikan teks lisan dan tulisan dengan menggunakan aksara dan angka dalam bahasa Indonesia. Keaksaraan usaha mandiri merupakan kemampuan atau keterampilan dasar usaha yang dilatihkan melalui pembelajaran produktif dan keterampilan bermatapencaharian yang dapat meningkatkan keaksaraan dan penghasilan, baik secara perorangan maupun kelompok sebagai salah satu upaya penguatan keaksaraan sekaligus pengentasan kemiskinan. Kondisi seperti ini akan diberikan sentuhan akademik dalam bentuk kecakapan hidup (life skill) berupa keterampilan ekonomi kreatif berupa kerajinan untuk meningkatkan pendapatan. Sekarang perempuan dituntut aktif secara ekonomi, meskipun disisi lain ada juga tuntutan agar perempuan yang berkeluarga dapat menghasilkan uang tanpa mengganggu fungsinya sebagai istri dan ibu rumah tangga. Saat ini fenomena perempuan bekerja bukan lagi barang aneh dan bahkan dapat dikatakan sudah merupakan tuntutan bagi perempuan untuk berpartisipasi dalam dunia kerja, yang dapat menaikkan harkat perempuan, yang sebelumnya selalu dianggap hanya sebagai pengurus anak, suami, dan rumah tangga semata-mata (Nainggolan, 2013).

\section{INJAUAN PUSTAKA}

Perempuan sebagai warga negara yang memiliki hak dan kewajiban yang sama dengan laki-laki, namun dalam bidang pendidikan dan ekonomi, banyak perempuan Indonesia yang tidak memiliki kemampuan memperoleh peluang kerja karena keterbatasan atau tidak bisa mengolah potensi yang ada pada dirinya maka perlunya pemberdayaan perempuan (Karwati, 2017).

Pemberdayaan merupakan salah satu wadah yang dijadikan sebagai upaya untuk memberikan wahana bagi masyarakat dalam memenuhi akan kebutuhan warga belajar berupa pengetahuan dan keterampilan yang berkaitan bagi kehidupan yang lebih baik di dalam kehidupan keluarga dan masyarakat (Karwati, 2017). Pengembangan kewirausahaan untuk meningkatkan ekonomi masyarakat melalui pendidikan nonformal. Program pendidikan nonformal yang pada dasarnya adalah proses pemberdayaan masyarakat diharapkan menjadi titik awal untuk meningkatkan kesejahteraan masyarakat. Upaya mengatasi persoalan tersebut, diperlukan model Pemberdayaan Masyarakat untuk meningkatkan Kewirausahaan Usaha Mandiri dan pada 
akhirnya mampu meningkatkan status sosial ekonominya.

Menciptakan wirausaha (Entrepreneurship) yang tangguh tidaklah mudah, karena diperlukan prasyarat-prasyarat tertentu, di antaranya adalah mampu menatap masa dengan lebih baik, memiliki orientasi kreatif dan perspektif (Mulyono, 2015). Dengan demikian maka sebaiknya dalam pengembangan sumber daya perempuan sebaiknya diarahkan untuk membentuk manusia yang (1) memiliki motivasi dan etos kerja yang tinggi, (2) menguasai banyak ilmu dan keterampilan, (3) memiliki sikap mental yang konsisten yang diwujudkan dalam komitmennya pada bidang pekerjaan tertentu (profesional), (4) memiliki semangat dan kemampuan bersaing (kompetitif), dan (5) memiliki budaya yang didasari pada nilai-nilai agama dan humanisme (Nurwahidah, n.d.).

Berdasarkan hasil pengamatan yang dilakukan di Desa Bahari Kecamatan Sampolawa Kabupaten Buton Selatan masalah utama yang dihadapi adalah perempuan putus sekolah cukup tinggi serta tidak memiliki keterampilan. Melihat situasi permasalahan tersebut di atas maka kami melaksanakan kegiatan Pengabdian Kepada Masyarakat (PKM) di Desa Bahari Kecamatan Sampolawa Kabupaten Buton Selatan.

Kegiatan PKM ini dilaksanakan oleh dosen dan mahasiswa program studi ilmu pemerintahan Universitas Muhammadiyah Buton. Kegiatan pengabdian ini tidak hanya sebagai perwujudan tanggung jawab dosen untuk melaksanakan tanggungjawab dalam hal tridharma perguruan tinggi yang dilaksanakan rutin setiap tahun pada masyarakat, melainkan juga sebagai sebuah kegiatan yang memberikan pengalaman kepada masyarakat khusunya perempuan. Kegiatan ini tentunya akan menambah wawasan sekaligus melengkapi keterampilan dosen.

Kegiatan pengabdian kepada masyarakat
(PKM) ini diselenggarakan di Desa Bahari Kecamatan Sampolawa Kabupaten Buton Selatan, adapun tujuan dari pengabadian kepada masyarakat ini, yaitu memberikan bekal pengetahuan kepada peserta Keaksaraan Usaha Mandiri dan keterampilan kepada peserta Keaksaraan Usaha Mandiri melalui pembelajaran keterampilan.

\section{METODE PELAKSANAAN}

Metode yang digunakan merupakan metode pemberdayaan masyarakat yang terdiri dari Ceramah, Curah Pendapat, Diskusi. Adapun populasinya adalah warga Desa Bahari khususnya perempuan. Usia 15-49 tahun, Kegiatan pengabdian ini dilaksanakan dalam bentuk penyuluhan dengan pendampingan, kegiatan ini dilaksanakan pada tanggal 25-27 November 2020. Adapun output yang menjadi target dalam pengabdian ini adalah Peserta Keaksaraan Usaha Mandiri mempunyai bekal pengetahuan dan keterampilan.

Adapun tahapan pelaksanaan kegiatan pengabdian pada masyarakat secara lengkap dapat dilihat pada Tabel berikut:

Proses pelaksanaan kegiatan yang telah dilakukan dalam rangka meningkatkan Kewirausahaan Usaha Mandiri di Desa Bahari memberikan pendidikan keaksaraan usaha mandiri untuk meningkatkan kemampuan atau keterampilan dasar usaha yang dilatihkan melalui pembelajaran produktif dan keterampilan bermata pencaharian yang dapat meningkatkan keaksaraan dan penghasilan, baik secara perorangan maupun kelompok sebagai salah satu upaya penguatan keaksaraan sekaligus pengentasan kemiskinan. 
Tabel 1. Tahapan pelaksanaan kegiatan pengabdian

\begin{tabular}{|c|l|c|l|}
\hline No & \multicolumn{1}{|c|}{ Tahapan Kegiatan } & Metode yang Digunakan & \multicolumn{1}{c|}{ Keterangan } \\
\hline 1 & Penetapan Wilayah Mitra & Pertemuan dan diskusi & $\begin{array}{l}\text { Tim PKM, kepala desa, dan } \\
\text { aparatur perangkat desa }\end{array}$ \\
\hline 2 & $\begin{array}{l}\text { Melakukan koordinasi Tim } \\
\text { guna penyelenggaraan } \\
\text { kegiatan pengabdian kepada } \\
\text { masyarakat }\end{array}$ & Pertemuan dan diskusi & $\begin{array}{l}\text { Tim PKM, kepala desa, dan } \\
\text { masyarakat }\end{array}$ \\
\hline 3 & $\begin{array}{l}\text { Kegiatan Pengabdian pada } \\
\text { masyarakat dilaksanakan } \\
\text { melalui penyuluhan dan } \\
\text { pelatihan }\end{array}$ & Pertemuan dan diskusi & Tim PKM dan masyarakat \\
\hline
\end{tabular}

\section{HASIL DAN PEMBAHASAN}

\section{$1.1 \quad$ Sosialisasi}

Sosialisasi dalam meningkatkan keaksaraan usaha mandiri merupakan kegiatan yang sangat penting, hal tersebut karena keaksaraan pada umumnya masih asing bagi sebagian masyarakat yang berada pada kawasan atau daerah tertinggal dan terbelakang atau daerah terpencil. Sosialisasi dimaksudkan untuk memperkenalkan program Keaksaraan Usaha Mandiri kepada masyarakat dan sasaran terkait dengan pelaksanaannya. Warga mendapatkan sosialisasi tentang bagaimana bentuk kegiatannya, cara pelaksaaannya, siapa yang melaksanakan, berapa lama berlangsung, dan apa saja yang menjadi hak dan kewajiban warga dalam mengikuti kegiatan PKM. Sosialisasi dilaksanakan beberapa kali, agar kegiatan Keaksaraan Usaha Mandari dapat dipahami dan dimengerti oleh masyarakat sebagai sasaran. Selain itu, agar kegiatan ini mendapat dukungan.

\subsection{Pelaksanaan Kegiatan}

Kegiatan pemberdayaan perempuan dalam meningkatkan keaksaraan usaha mandiri pertam-tama dilakukan persiapan pembelajaran, kegiatan ini meliputi:

a. Penyiapan rencana dan jadwal kegiatan yang dituangkan dalam Acuan Pelaksanaan.

b. Sosialisasi dan koordinasi pelaksanaan kegiatan.

c. Pelaksanaan Pembelajaran yang mengacu pada Standar Kompetensi Keaksaraan Usaha Mandiri. Setiap kelompok belajar minimal 10 peserta didik.

d. Penyelenggaraan bersama program Tim PKM dan peserta, membuat kesepakatan (kontrak belajar). Kontrak belajar mencakup jadwal, tempat, waktu dan tata tertib.

e. Kegiatan pembelajaran/keterampilan dasar usaha.

Khusus pada kegiatan pembelajaran/ keterampilan dasar usaha dilakukan secara terstruktur yaitu mengungkapkan keinginan berusaha berdasarkan minat dan potensi yang tersedia; mempraktikkan sebuah keterampilan yang berpeluang menjadi bidang usaha sesuai minat dan potensi yang dimiliki: menyusun rancangan usaha dan menjalankan usaha mandiri yang dikembangkan; merancang dan mengelola 
biaya pada usaha yang akan dikembangkan; mengidentifikasi risiko-risiko yang mungkin timbul dan mempengaruhi laba rugi usaha; memahami strategi pemasaran; mengenali kekuatan pesaing dalam pasar produk yang dikembangkan; menjalin kemitraan; dan menjaga kelangsungan usaha yang dikembangkan.

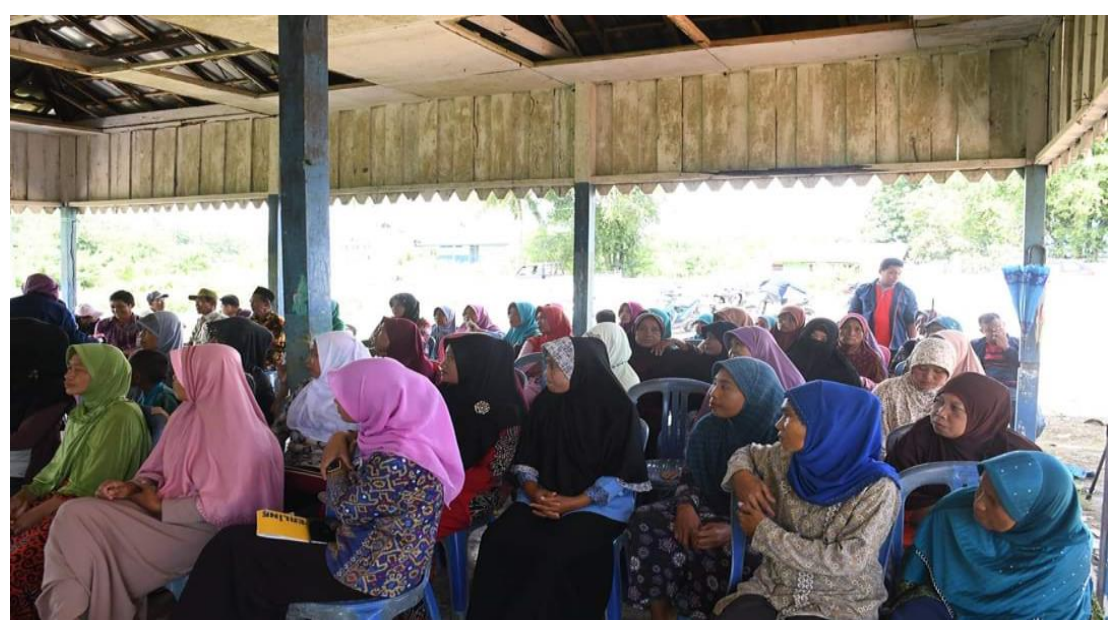

Gambar 1. Sosialisasi Tim PKM Tentang Meningkatkan Keaksaraan Usaha Mandiri Melalui Pemberdayaan Perempuan

Tabel 2. Materi Kegiatan PKM Keaksaraan Usaha Mandiri

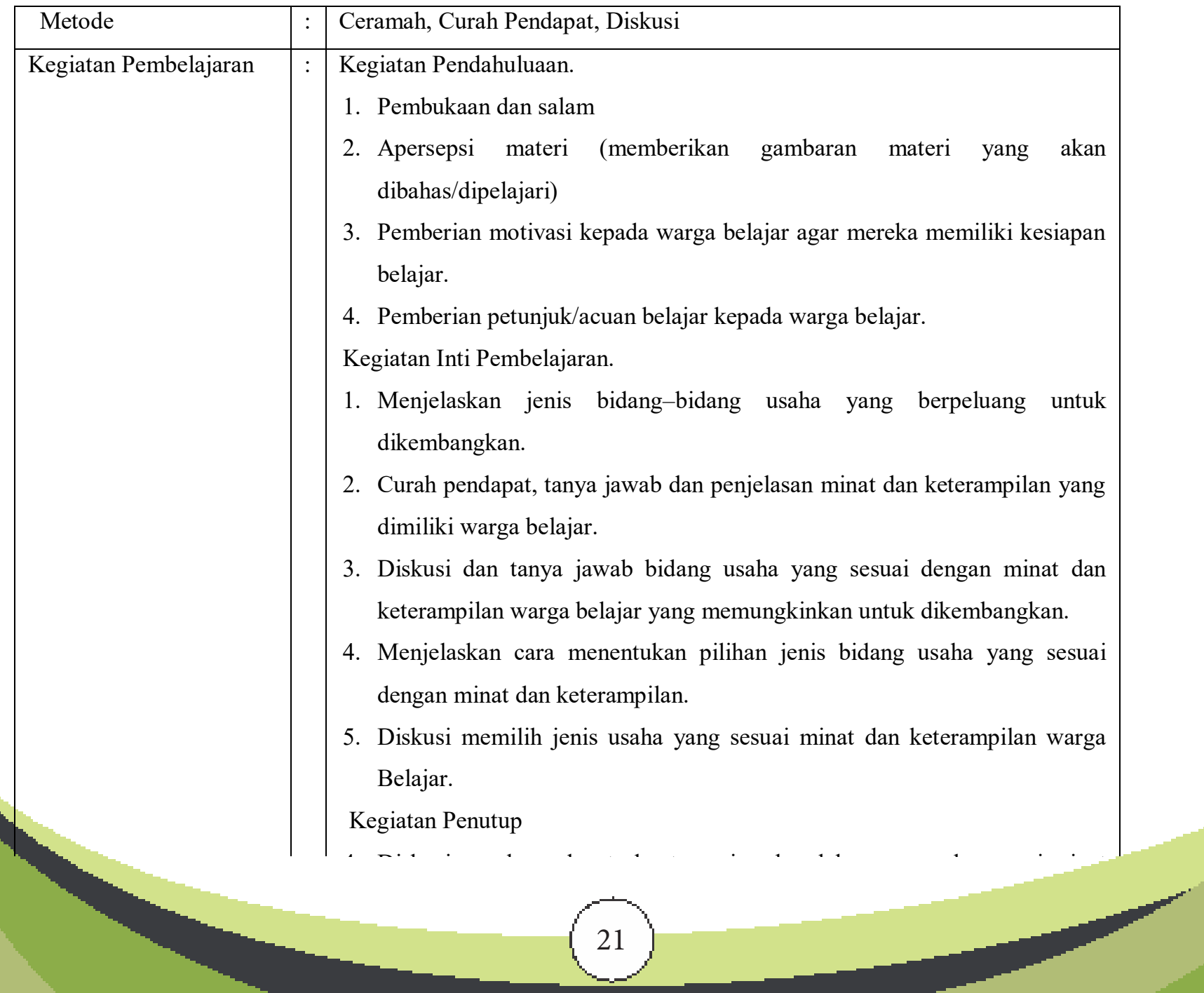




\begin{tabular}{|c|c|c|}
\hline & & $\begin{array}{l}\text { 4. Diskusi, curah pendapat, dan tanya jawab pelaksanaan usaha sesuai minat } \\
\text { dan keterampilan warga belajar. } \\
\text { 5. Diskusi dan curah pendapat untuk memutuskan jenis usaha yang akan } \\
\text { dikembangkan baik secara individu maupun berkelompok. } \\
\text { 6. Diskusi, curah pendapat, dan tanya jawab menyusun persiapan - persiapan } \\
\text { pelaksanaan kegiatan usaha sesuai minat dan keterampilan usaha. } \\
\text { 7. Menyimpulkan kesepakatan tentang jenis usaha yang akan dikembangkan. }\end{array}$ \\
\hline Sumber Belajar & $:$ & Buku - buku pengembangan dan pemilihan usaha. \\
\hline Materi belajar & : & $\begin{array}{l}\text { 1. Minat dan keterampilan usaha yang dimiliki warga belajar. } \\
\text { 2. Mengidentifikasi bidang-bidang usaha yang berpotensi untuk } \\
\text { dikembangkan. } \\
\text { 3. Bidang-bidang usaha yang sesuai dengan minat dan keterampilan warga } \\
\text { belajar. } \\
\text { 4. Teknik memilih bidang usaha yang sesuai minat dan keterampilan. } \\
\text { 5. Perencanaan kegiatan usaha }\end{array}$ \\
\hline
\end{tabular}

\section{KESIMPULAN}

Berdasarkan kegiatan pengabdian tentang meningkatkan keaksaraan usaha mandiri dengan pemberdayaan perempuan, mulai dari awal pelaksanaan yakni penetapan desa mitra, pelaksanaan kegiatan penyampaian materi meningkatkan keaksaraan usaha mandiri dengan pemberdayaan perempuan, dapat disimpulkan bahwa kegiatan pengabdian seperti ini sangat dinantikan oleh warga belajar khususnya perempuan usia 15-59 tahun dalam upaya pengembangan dan pemilihan usaha. Perempuan usia 15-59 tahun yang menjadi target sasaran kegiatan pengabdian ini sangat antusias mengikuti kegiatan penyampaian materi melalui ceramah dan diskusi.

\section{DAFTAR PUSTAKA}

Hening Ratri. (2015). Pelaksanaan Program Keaksaraan Usaha Mandiri (Kum) Dengan Pemberdayaan Masyarakat Di Pkbm Handayani Dea Baureno Kecamatan Baureno Kabupaten Bojonegoro. J+Plus Unesa,4(1), 1-11.https://jurnalmahasiswa. unesa.ac.id/index.php/jurnal-pendidikanluar-sekolah/article/view/13236

Karwati, L. (2017). Pemberdayaan Perempuan Melalui Pelatihan Woman Empowerment Through Entrepreneurs Training. Jurnal Ilmiah Visi PGTK PAUD Dan Dimas, 12(1), 45-52. https://media.neliti.com/media/ publications/259938-pemberdayaanperempuan-melalui-pelatihan-5d1ad68b. pdf

Nainggolan, D. Y. (2013). PEMBERDAYAAN DAN PENGEMBANGAN WIRAUSAHA PEREMPUAN MUDA PADA RUMAH TANGGA MISKIN DI KECAMATAN MEDAN DELI KOTA MEDAN. JURNAL ILMU SOSIAL-FAKULTAS ISIPOL UMA, 6(April), 14-29.

Nurwahidah, H. L. S. (n.d.). PEMBERDAYAAN PEREMPUAN MELALUI PEMBELAJARAN LITERASI BERORIENTASI KEAKSARAAN USAHA MANDIRI. Jurnal Ilmiah Program Studi Pendidikan Bahasa Dan Sastra Indonesia, 55-67. 